University for Business and Technology in Kosovo

UBT Knowledge Center

UBT International Conference

2014 UBT International Conference

Nov 7th, 5:00 PM - 5:15 PM

\title{
The relationship between economic growth and eucation in
}

\section{Albania}

Marie Guma

Kocaeli University, marie.guma@hotmail.com

Follow this and additional works at: https://knowledgecenter.ubt-uni.net/conference

Part of the Business Commons

\section{Recommended Citation}

Guma, Marie, "The relationship between economic growth and eucation in Albania" (2014). UBT International Conference. 39.

https://knowledgecenter.ubt-uni.net/conference/2014/all-events/39

This Event is brought to you for free and open access by the Publication and Journals at UBT Knowledge Center. It has been accepted for inclusion in UBT International Conference by an authorized administrator of UBT Knowledge Center. For more information, please contact knowledge.center@ubt-uni.net. 


\title{
The relationship between economic growth and eucation in Albania
}

\author{
Marie Guma \\ Institute of Social Sciences, Kocaeli University, Kocaeli, Turkey \\ marie.guma@hotmail.com
}

\begin{abstract}
Albania as a middle-income country has faced an ongoing economic growth even though economic crisis have stroked world's economy. The economic growth itself explains at the same time the increase in a nation's welfare by all means of it. However our main focus is the effect that education level of individuals has on the economic growth of Albania. Literature review states that investment in education directs into the formation of a qualified human capital, compared to physical or social capital and that makes a significant contribution to economic growth. So the study will briefly explain the reasons behind the economic growth of Albania and the education in this country between the years 1994-2011 by showing a detailed way of how this effect has contributed in the overall growth of economy. Thus, in order to explain the before mentioned relationship of the importance of education in economic growth of Albania, supporting the theoretical findings we will execute various econometric analyses such as Unit Root Test, Cointegration, Granger Casuality Test and at last VAR analasys using the EViews. 5.0 package.
\end{abstract}

Keywords: Albanian economy, education, economic growth.

\section{Introduction}

There is a different concept when talking about economic growth and economic development even though these two terms are used sometimes as synonyms in different kind of literatures. Economic growth reflects an increase in production capacity and what is more important a rise in national income and income per capita. Economic development itself includes an increase in investments, production and technology, real income and apart from these, an increase in the levels of education together with a continuous alteration in socio-economic environment takes place.

According to this explanation, beside income per capita the significance of social and cultural environment is a key factor. Thus, in such circumstances it is not just economic growth that is being evaluated but economic development too.

The main focus of this paper is to show the relationship that exists between education and economic growth, yet the central objective will be to find whether there is a link between average education years and Gross Domestic Product in the short and long run for the case of Albania (a developing country) The specific objectives of this study are to:

1. Examine the short-run stability of education and GDP in Albania;

2. Show the short and long run co integrated relationship between education and economic growth;

3. Analyze causality between education and economic growth;

4. Perform a VAR analysis to show the results of our study.

So in order to help us fulfill the objectives of this paper in the previous chapters we will discuss matters as follows: Firstly we will explain some background on education and growth in Albania, after that discuss theoretical precursors of the related topic. In the third chapter of this paper empirical precursors and an explanation of our empirical strategy will be presented. Lastly we will suggest and write our own conclusions based on the empirical work in the case of Albania. 


\section{Some Background on Education and Growth in Albania}

Albania as a middle-income country has made obvious improvements in settling a credible, poly-partial type of democracy and a successful market economy over the last 20 years. During these transition years, Albania has generally been capable to attain positive growth rates and financial stability, despite the ongoing economic crisis. During this time, Albania was considered as one of the economies which were facing a fast grow and moreover a rapid reduction in poverty before the global financial crisis. The average annual real growth rates of $6 \%$ were almost halved after 2008 and were accompanied by macroeconomic imbalances in the public and external sectors. As a result of the slow economic growth the effects on poverty and unemployment were negative too: between 2002 and 2008, a period where Albania was experiencing an obvious growth, poverty in the country fell by half (to about $12.4 \%$ ) but in 2012 it increased again to $14.3 \%$. On the other hand, unemployment increased from $12.5 \%$ in 2008 to $16.9 \%$ in 2013 , with youth unemployment reaching $26.9 \%$. Even though Albania is considered as one of the countries that did not experienced most of the negatives effects of the last global crisis and moreover, being one of the few countries with rising economic growth during the last one, a slight decrease on growth has been shown. The recovery to growth rates above 3\% in 2011 moderated in 2012 and 2013, reflecting the deteriorating situation in the Eurozone and the difficult situation in the energy sector. Real Gross Domestic Product (GDP) growth dipped to a low point of $0.4 \%$ in the third quarter of 2013 . A rebound of $2.1 \%$ is expected in 2014 , but growth is also expected to stay below the countries potential over the medium term. (WorldBank, 2014). Education in Albania remains one of the most indispensible policy priorities aiding democracy and improving social interaction in society, as well as creating skilled and adaptable workforce contributing as such in the country's economy directly.

The Albanian education system is organized as follows: pre-school education, mainly provided by kindergartens; basic education (grades 1-9), which is free and compulsory; secondary education (general, social-cultural and vocational); and higher education. Given the importance of education school enrollment, compulsory education's rates are almost $100 \%$, while enrollment during secondary education changes roughly. For example, the share of vocational education students in total secondary enrolments declined sharply, from $72 \%$ to $19 \%$, between 1990 and 2002, mainly as a result of the closure of many vocational and multi programme secondary schools which offered both vocational education and general secondary education programmes (Nikolovska, 2008). Still, in the past years various informative campaigns have been held and immense investments have been made to increase these numbers.Both the employment and unemployment rates for the 'adults' group by level of education show that higher education is associated with more advantaged performance in the labor market. A similar advantage was observed with unemployment rates, in which the deviation to country average was approximately $50 \%$ or more. Thus, it is mostly the labor force with only secondary education that faces severe challenges in the labor market. In this study we are going to see the relationship that exists between economic growth of Albania and education, as one of the most important ways of investment in human capital. We will investigate whether this relationship is a long or short run relationship and furthermore if it is uni or bi-directed in the following chapters.

\section{Theoretical Precursors}

Investment in education directs through formation of a qualified human capital, compared to physical or social capital and that makes a significant contribution to economic growth. Education as an investment secures returns in the form of skilled manpower that increases the need of development, both accelerating economic development and for improving the quality of the society. (Islam, 2014) In a society with highly-educated individuals the probability to break the law is low. On the other side educated individuals are more precautious to take care of their own state of health leading thus to a more qualified human capital. So we can say that a society with more educated individual will have no problems such as paying taxes, because the capacity to pay taxes more will increase. (Altundemir, 2012)

Education has a big importance in economy, especially in developing economies like Albania because it is included in one of the key factors that gears economic growth process. On one side education can 
affect poverty by decreasing it, because as an economy develops the need for highly-educated workers will increase leading thus to a vast need on education levels. So, an educated individual will make him/herself firstly a potential employee affecting wages and decreasing poverty in general. On the other side, as we have mentioned it even before education increases economic growth since it is an indicator that affects both in micro and macroeconomic levels. In order to explain such a relation, Katharina Michaelowa (2000) explains in a diagram the impact of education as follows

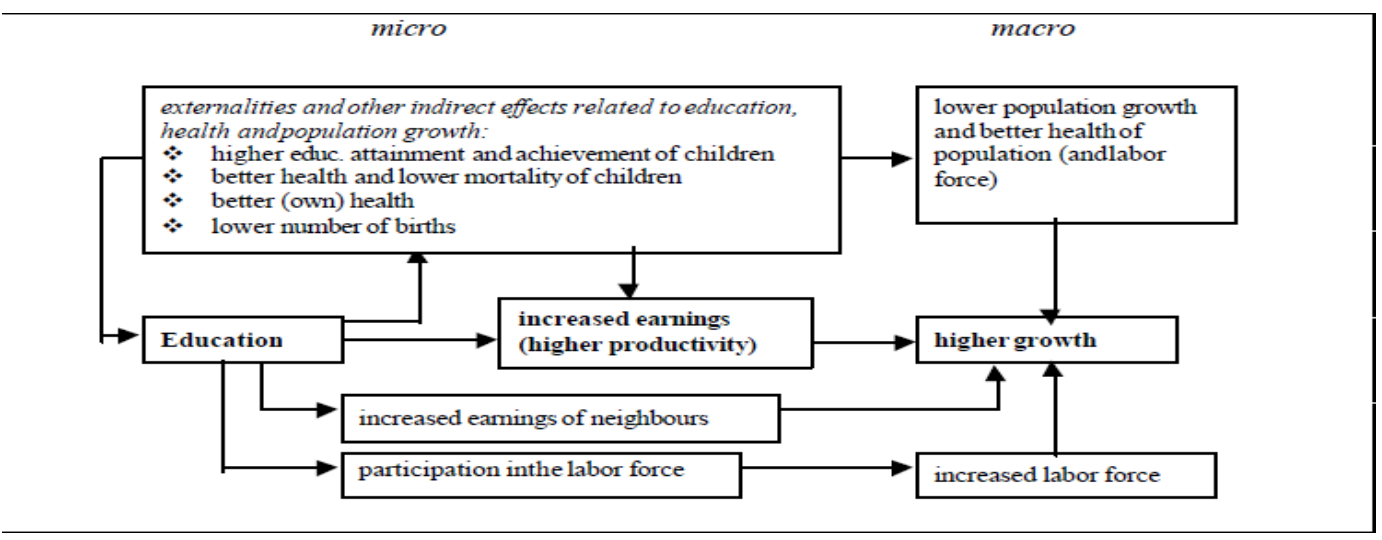

\section{Figure 1: Economic Returns to Education}

After knowing all the impact that education has on economy we will try to build all the indicators that will help us form a model for explaining this kind of relationship in the case of Albania. Various different authors have tried to make such a study in order to explain the effects that education has on economic growth or vice versa. Above all we can say that for the first time it was Adam Smith (1776) and the classical economists that emphasized for the first time the importance of investment in human capital, and to come to one of the latest authors who has made significant research in such topic Barro (1997) focuses more in human capital as a indispensable determinant of economic growth. Even though human capital includes education, health and aspects of 'social capital' the focus of our study will be directed at education only.

During this attempt of explaining the relationship of human capital, i.e. education and economic growth the main model has been developed from normal neo-clasic type of human capital model of Solow $Y=$ $(K, L, t)$ where $\mathrm{Y}$ is production, $\mathrm{K}$ is Physical capital, $\mathrm{L}$ is labor force and $\mathrm{t}$ shows that the function is time-dependend, to a model of endogeneous growth.

The model of endogenous growth was firstly explained by Romer and Lucas and included in a CobbDouglas type of function ecuation technology and human capital in the form of $Y=A K^{a} H^{b} L^{1-a-b}$. The recent endogeneous-growth models are useful for understanding why advanced economies and the world as a whole can continue to grow in the long run despite the workings of diminishing returns in the accumulation of physical and human capital (Barro, Education and Economic Growth, 2013).

\section{Literature Review and Empirical Precursors}

Various economic studies have used different variables to show and explain the relationship that exists between education and economic growth. Education expenses, education levels, enrollment rates, average school years etc are some of the variables that have been used by different authors in their empirical studies that have been tried to put into evaluation the exact relationship of education and economic growth in different countries.

In the following table we have gathered together some of this papers' empirical results and present it as follows: 
Table 1: Methodological Studies

\begin{tabular}{|c|c|c|c|c|c|c|}
\hline Author & Period & $\begin{array}{l}\text { Countr } \\
\mathbf{y}\end{array}$ & $\begin{array}{l}\text { Independent } \\
\text { Variables }\end{array}$ & $\begin{array}{l}\text { Dependen } \\
\text { t Variable }\end{array}$ & Method & Results \\
\hline $\begin{array}{l}\text { (Özsoy, } \\
2009)\end{array}$ & $\begin{array}{l}1923- \\
2005\end{array}$ & Turkey & $\begin{array}{l}\text { Elementary, } \\
\text { Secondary, } \\
\text { Professional and } \\
\text { Univeersity } \\
\text { school's students } \\
\text { number. }\end{array}$ & Real GDP & $\begin{array}{l}\text { VAR } \\
\text { analysis }\end{array}$ & $\begin{array}{l}\text { Positive } \\
\text { relationshi } \\
\mathrm{p} \text { in long- } \\
\text { run }\end{array}$ \\
\hline $\begin{array}{l}\text { (Bozkur } \\
\mathrm{t}, 2010)\end{array}$ & $\begin{array}{l}1980- \\
2005\end{array}$ & Turkey & $\begin{array}{l}\text { Life expectancy, } \\
\text { Health expenses } \\
(\% \text { GDP }) \text {, } \\
\text { Enrollment rate of } \\
\text { elementary, } \\
\text { secondory and } \\
\text { tertiary education, } \\
\text { total saving (all ln) }\end{array}$ & $\begin{array}{l}\text { GDP per } \\
\text { capita }\end{array}$ & $\begin{array}{l}2 \quad \text { step } \\
\text { Enlges, } \\
\text { Johansen } \\
\text { and Stock } \\
\text { Watson } \\
\text { Analysis }\end{array}$ & $\begin{array}{l}\text { Positive } \\
\text { reationship } \\
\text { in long run }\end{array}$ \\
\hline $\begin{array}{l}\text { (Erdoğa } \\
\mathrm{n} \& \\
\text { Yıldırı } \\
\mathrm{m}, \\
2009)\end{array}$ & $\begin{array}{l}1975- \\
2005\end{array}$ & Turkey & $\begin{array}{l}\text { Total education } \\
\text { expenses, primary, } \\
\text { secondary and } \\
\text { tertiary education } \\
\text { spendings, } \\
\text { education } \\
\text { investments }\end{array}$ & GDP & $\begin{array}{l}\text { ARDL } \\
\text { Method }\end{array}$ & $\begin{array}{l}\text { No } \\
\text { relationshi } \\
\mathrm{p} \text { in short } \\
\text { run, } \\
\text { Positive } \\
\text { relationshi } \\
\mathrm{p} \text { in long } \\
\text { run }\end{array}$ \\
\hline $\begin{array}{l}\text { (Afzal, } \\
\text { Malik, } \\
\text { Begum, } \\
\& \\
\text { Fatima, } \\
\text { 2012) }\end{array}$ & $\begin{array}{l}1971- \\
2010\end{array}$ & Pakistan & $\begin{array}{l}\text { Physical gross } \\
\text { fixed capital } \\
\text { formation, } \\
\text { education index, } \\
\text { poverty index }\end{array}$ & Real GDP & ARDL & $\begin{array}{l}\text { Positive in } \\
\text { short and } \\
\text { long run, } \\
\text { Positive in } \\
\text { long run, } \\
\text { Negative } \\
\text { in long run }\end{array}$ \\
\hline $\begin{array}{l}\text { (Reza \& } \\
\text { Valeech } \\
\text { a, 2012) }\end{array}$ & $\begin{array}{l}1981- \\
2010\end{array}$ & Pakistan & $\begin{array}{l}\text { Government } \\
\text { expenditure on } \\
\text { education, labor } \\
\text { force participation } \\
\text { rate, gross fixed } \\
\text { capital formation }\end{array}$ & Real GDP & OLS & $\begin{array}{l}\text { No long } \\
\text { term } \\
\text { relationshi } \\
\mathrm{p}\end{array}$ \\
\hline $\begin{array}{l}\text { (Islam, } \\
\text { 2014) }\end{array}$ & $\begin{array}{l}1973- \\
2010\end{array}$ & $\begin{array}{l}\text { Banglad } \\
\text { esh }\end{array}$ & $\begin{array}{l}\text { Revenue } \\
\text { expenditures, } \\
\text { Development } \\
\text { expenditures, Total } \\
\text { Education } \\
\text { expenditures }\end{array}$ & $\begin{array}{l}\text { GDP at } \\
\text { current } \\
\text { price }\end{array}$ & $\begin{array}{l}\text { VAR } \\
\text { analysis }\end{array}$ & $\begin{array}{l}\text { Positive } \\
\text { but uni- } \\
\text { direction. }\end{array}$ \\
\hline $\begin{array}{l}\text { (Abhije } \\
\text { et, } \\
2010)\end{array}$ & $\begin{array}{l}1951- \\
2009\end{array}$ & India & $\begin{array}{l}\text { Primary, secondary } \\
\text { and tertiary } \\
\text { education expenses }\end{array}$ & GDP & $\begin{array}{l}\text { Linear and } \\
\text { non-linear } \\
\text { Granger } \\
\text { Casuality }\end{array}$ & $\begin{array}{l}\text { Positive in } \\
\text { long run } \\
\text { and bi- } \\
\text { direction. }\end{array}$ \\
\hline
\end{tabular}

As seen from different papers and studies the relationship that education and economic growth have with each other is mainly positive in long run because it is in long run that it effects even a individual's future possible earnings. According to the returns from education a preson should choose to do an extra year of education only if the future returns will be greater than the expenses of education in the present. 


\section{Empirical Strategy}

In this part of our paper we will explain the relation between education end economic growth in Albania during the years 1994-2011. We will perform econometric analyses such as Unit Root Test, Cointegration, Granger Casuality Test and at last VAR analasys. The variables that we are using in this study are change in real GDP (which in other words is explained as growth rate), number of student at high schools, profesional schools and universities. We do not use in our study primary school since primary school is an obligation level of study required by law. We have gained our datas form Albania's Institute of Statistics and we are using Eviews Package 5.0 in order to recieve our results of the model.

\subsection{Unit Root Test Results}

The variables used in VAR Analisys should be stationary for this reasons after we have excecuted Augmented Dickey-Fuller (ADF) unit root test we get the following results

\begin{tabular}{llllllc}
\hline Variables & Nivel & Lag & Probability & $\begin{array}{l}\text { 1st/2nd } \\
\text { Diff }\end{array}$ & Lag & Probability \\
\hline GDP & -2.5 & 1 & 0.322 & -2.26 & 1 & 0.0269 \\
HİG & -4.05 & 3 & 0.033 & & & \\
PROF & -2.69 & 3 & 0.251 & -2.38 & 1 & 0.0207 \\
UNI & 0.73 & 0 & 0.999 & $-6.73^{*}$ & 0 & 0.0000 \\
\hline
\end{tabular}

*second difference

According to unit root tests GDP is Integrated in level 1, I(1); HİGH is I(0); PROF is I(1) and UNI is $\mathrm{I}(2)$.

\subsection{Cointegration Test}

After having controlled about stationary we are going to examine whether between our variables exist a relationship in long run. We use Johansen Method to achieve this desired result.

\begin{tabular}{ccccc}
\hline \multicolumn{4}{l}{ Unrestricted Cointegration Rank Test (Trace) } & 0.05 \\
Hypothesized & \multicolumn{1}{c}{ Trace } & Critical Value & Prob.** \\
No. of CE(s) & Eigenvalue & Statistic & 47.85613 & 0.0001 \\
None * & 0.868000 & 70.87097 & 29.79707 & 0.0039 \\
At most $1 *$ & 0.746515 & 38.47171 & 15.49471 & 0.0350 \\
At most 2* & 0.560890 & 16.51250 & 3.841466 & 0.0674 \\
At most 3 & 0.188626 & 3.344426 & \\
Trace test indicates 3 cointegrating eqn(s) at the 0.05 level & & \\
$*$ denotes rejection of the hypothesis at the 0.05 level & & \\
$* *$ MacKinnon-Haug-Michelis (1999) p-values & \\
\hline
\end{tabular}

There are at least 2 variables which have a long term relationship with each other at the level \%5. So we can say that between GDP, HIGH, PROF and UNI exits a stable long-term relationship at at least two of these variables. Moreover to find this kind of relationship we should use Granger Casuality Test to see in particularly which are these two variables.

\subsection{Granger Casuality Test}

Pairwise Granger Causality Tests

Sample: 19942011

Lags: 2 
$3^{\text {rd }}$ International Conference on Business, Technology and Innovation

\begin{tabular}{lccc}
\hline Null Hypothesis: & Obs & F-Statistic & Probability \\
HIGH does not Granger Cause GDP & 16 & 14.0877 & 0.00092 \\
GDP does not Granger Cause HIGH & & 0.19971 & 0.82187 \\
PROF does not Granger Cause GDP & 16 & 5.47019 & 0.02243 \\
GDP does not Granger Cause PROF & & 0.94418 & 0.41838 \\
UNI does not Granger Cause GDP & \multirow{2}{*}{16} & 1.06430 & 0.37797 \\
GDP does not Granger Cause UNI & & 0.86402 & 0.44820 \\
PROF does not Granger Cause HIGH & \multirow{2}{*}{16} & 0.66789 & 0.53241 \\
HIGH does not Granger Cause PROF & & 2.06100 & 0.17370 \\
UNI does not Granger Cause HIGH & \multirow{2}{*}{16} & 2.92450 & 0.09583 \\
HIGH does not Granger Cause UNI & & 2.63347 & 0.11627 \\
UNI does not Granger Cause PROF & \multirow{2}{*}{16} & 0.17791 & 0.83938 \\
PROF does not Granger Cause UNI & & 0.62315 & 0.55416 \\
\hline
\end{tabular}

According to Granger casuality test :

- High school education causes a GDP increase

- Professional school education causes a GDP increase

- There is no relationship between other variables

Lastly we are going to execute our last analysis which is VAR Analysis but before doing this we need to know in which place we are going to list our variables in the regression. According to the beforeapplied test GDP, UNI, PROF, HIGH will be the listing of the variables.

\subsection{VAR Impulse Response Analysis}
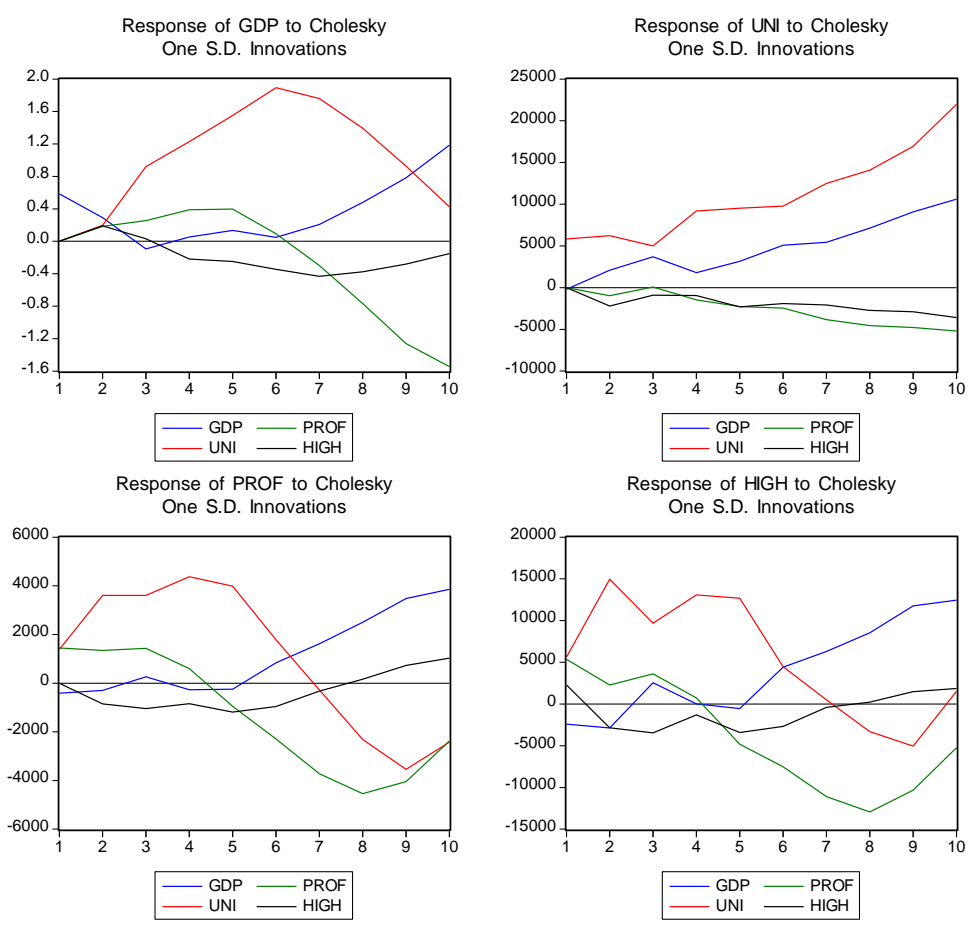
Whenever there is a shock in GDP the UNI (University Student Number) variable will move in the same direction with the shock. PROF (Professional High School Student Number) will move in the same direction for at least 5 period and then move in different direction with the shock. HíGH (High School Student Number) will be affected negatively for at least 8 periods but after that will move in the same direction with the shock.

\section{Conclusions}

In this paper we studied the relationship that existed between education and economic growth during the years 1994-2011 with the help of VAR Analysis of the model. After doing the proper econometric model we get to the result that in fact there is a long term relationship but a uni-directional one between GDP and high and professional schools' number of student. But after examining the direction of the variables we see that in case of any shock in the GDP growth only HIGH and PROF will be affected in different ways for different periods of time, while other variables behave in the same way. The fact that University's number of student do not affect GDP may be the fact that the returns from an extra year of high or professional schooling will have a greater return than an extra year of University school year.

\section{References}

1) Abhijeet, C. (2010). Does Government Expenditure on Education Promote Economic Growth? An Econometric Analysis. Munich Personal RePEc Archive .

2) Afzal, M., Malik, M. E., Begum, I., \& Fatima, H. (2012). Relationship among Education, Poverty and Economic Growth in Pakistan: An Econometric Analysis. Journal of Elementary Education .

3) Altundemir, M. E. (2012). Kalkınma Planlardan Eğitime Bakış: Kamusall Mallar Teorisi Perspektifinden. The Journal of Knowledge Economy \& Knowledge Management .

4) Barro, J. R. (1997). Determinants of Economic Growth, A cross country empirical study. Journal of Monetary Economics .

5) Barro, J. R. (2013). Education and Economic Growth. In Annals of Economics and Finance (pp. 277-304). Harvard University.

6) Bozkurt, H. (2010). Eğitim, Sağlik ve İktisadi Büyüme Arasındaki İlişkiler: Türkiye için bir Analiz. The Journal of Knowledge Economy \& Knowledge Management .

7) Erdoğan, S., \& Yıldırım, D. Ç. (2009). Türkiyede Eğitim- İktisadi Büyüme İlişkisi Üzerine Ekonometrik bir İnceleme. The Journal of Knowledge Economy \& Knowledge Management .

8) Islam, R. (2014). Education and Economic Growth in Bangladesh- An Econometric Study. Journal Of Humanities And Social Science, 102-110.

9) LSMS. (2014). Retrieved 06 26, 2014, from World Bank: http://econ.worldbank.org/WBSITE/EXTERNAL/EXTDEC/EXTRESEARCH/EXTLSMS/0, ,contentMDK:21610833 pagePK:64168427 piPK:64168435 theSitePK:3358997,00.html

10) Michaelowa, K. (2000). Returns to Education in Low Income Countries: Evidence for Africa. Committee on Developing Countries. Hamburg: Hamburg Institute for International Economics. 
11) Nikolovska, M. (2008). Human Resource Development Country Analysis. European Training Foundation.

12) Özsoy, C. (2009). Türkiyede Eğitim ve İktisadi Büyüme Arasındaki İlişkinin VAR Modeli ile Analizi. The Journal of Knowledge Economy and Knowledge Management .

13) Reza, A., \& Valeecha, S. (2012). Impact of Education on Economic Growth of PakistanEconometric Analysis. Journal of Business and Management .

14) WorldBank. (2014). $\quad$ Retrieved $06 \quad 25, \quad 2014, \quad$ from http://www.worldbank.org/en/country/albania/overview 